\title{
Fecundity and trapping of Varroa destructor (Mesostigmata: Varroidae) in Greek drone brood of Apis melifera (Hymenoptera: Apididae)
}

\author{
Petros T. Damos \\ Laboratory of Applied Zoology and Parasitology, Department of Plant Protection, \\ Faculty of Agriculture, Aristotle University of Thessaloniki, Greece
}

\begin{abstract}
This study estimates the parasitization levels and fecundity of the ectoparasitic mite Varroa destructor Oudemans in drone brood of bee colonies located in Northern Greece. Based on successive observations in spring and early summer, the study also examines whether early entrapment of mites into the drone brood cell decreases the mite population levels in the succeeding generation. Varroa populations in drone brood were extremely high (approx. 40\%) in early spring, although numbers dropped significantly (approx. 20\%) after the entrapment and removal of mites into the drone brood $(t=4.14518$, $\mathrm{P}=0.0136$, Mann-Whitney: $\mathrm{P}=0.005)$. In most cases, more than half of the inspected cells were occupied with two or more parental mites. No significant differences were found in the reproductive performance of the Varroa mites between the two successive generations in spring and early summer $(\mathrm{t}=-0.607, \mathrm{P}=0.554$, Mann-Whitney: $\mathrm{P}=0.128)$. The reproductive performance of $V$. destructor ranged from 1.5-3 progeny per female individual (m1:1.673, SE=0.09 and m2:2.02, SE: 0.44 for the first and second generations, respectively). A positive and significant correlation was observed between the drone and the mite populations $\left(y=0.830+1.153 x, F=8.851, P=0.41, R^{2}: 0.689\right.$ and $y=0.319+0.968 x$, $\mathrm{F}=45.276, \mathrm{R}^{2}: 0,938, \mathrm{P}=0.07$ for the first and second mite generations,
\end{abstract}

Correspondence: Petros T. Damos, Laboratory of Applied Zoology and Parasitology, Department of Plant Protection, Faculty of Agriculture, Aristotle University of Thessaloniki, 54124 Thessaloniki, Greece.

E-mail:damos@agro.auth

Key words: mite, varoatosis, reproduction, bee colonies, apiculture.

Acknowledgements: the author acknowledges the fruitful discussions made with M. Ifantidis on trial design and management.

Received for publication: 15 August 2012.

Revision received: 24 October 2012.

Accepted for publication: 29 0ctober 2012.

(C) Copyright P.T. Damos, 2012

Licensee PAGEPress, Italy

Journal of Entomological and Acarological Research 2012; 44:e18

doi:10.4081/jear.2012.e18

This article is distributed under the terms of the Creative Commons Attribution Noncommercial License (by-nc 3.0) which permits any noncommercial use, distribution, and reproduction in any medium, provided the original author(s) and source are credited. respectively). There were no significant differences in the number of infested and non-infested cells during the first observations (m1: 105.2, SE: 25.0, m2: 170.0 SE: 40.0, $\mathrm{t}=-1.38, \mathrm{P}=0.203$, Mann-Whitney: $\mathrm{n1}: 81.0$, n2:142.5, $\mathrm{P}=0.0656$ ). On the contrary, during the second observations the number of infested cells was significantly lower (m1: 27.6, SE:8.1, m2:262.8, SE:69.0, $\mathrm{t}=-3.39, \mathrm{P}=0.027$, Mann-Whitney: $\mathrm{P}=0.012, \mathrm{n} 1: 20, \mathrm{n} 2: 340)$.

\section{Introduction}

The mite Varroa destructor (jacobsoni) Oudemans (Anderson \& Trueman, 2000) is the most important ectoparasite of bee colonies that causes epizooty on its host Apis melifera (Hymenoptera: Apididae). The specimens belong to the superorder Anactinotrichida of the order Mesostigmata (or Gamasida) (Evans, 1992) and is characterized by the fact that all of its life stages are closely related to those of its host. Female individuals feed on the hemolymph of immature and adult bees, whereas nymphs and adult males feed only on immature bees (Colin $e t$ al., 1997). Females of the parasite enter the brood cells before cell capping and their reproductive period coincides with a capped period during which $A$. melifera complete their metamorphosis from the last larval stage through the pupal stage to the adult stage (Crane, 1978; Ifantidis, 1983; Martin, 1994; Fries et al., 1994; Rosenkranz et al., 2010).

The specimen was first described as a parasite of Apis cerana in Java by Oudemans (1904). Later it was identified in the Southeast Asian Malay Peninsula, Singapore in 1944 and in 1952 in the eastern coastal region of the former USSR (Crane, 1978; Rosenkranz et al., 2010). In the Indian peninsula, the mite was first recorded in Pakistan in 1955 and a few years later, in 1958 and 1959, it was identified in Japan and China, respectively. In the early 1960 s, the parasite was introduced in colonies of the Western bee A. melifera from the Asian honeybee species Apis cerana Fabricius (Martin, 1995). The parasite seems to have crossed the Mediterranean Sea in 1975 through the importation of colonies from Romania to Tunisia. In Greece, however, the regular presence of the parasite in bee colonies was observed in the late 1970s and early 1980s (Ifantidis 1983, 1984). Since then, its presence has been regularly observed, although possible alterations in its parasitic potential as related to regional host resistance has not yet been evaluated in detail.

Despite the fact that the original host of the Varroa mite is not damaged to any appreciable degree, mainly because infestation occurs in drone brood and mites become entrapped in dying drone brood (Rath \& Drescher, 1990; Fries et al., 2006), it causes significant problems to the Western honeybee A. melifera. It is thought that one of the reasons for this is the absence of a long period of co-evolutionary relationship, as in the case of A. cerana (Rath, 1999; Rosenkranz et al., 2010) and, therefore, in Europe the mite populations must be regularly controlled to avoid colony collapse. 
Generally, the reproductive potential and related fecundity of $V$. jacobsoni on $A$. melifera brood can be extremely high. There are instances in which a mother mite may reproduce a maximum of 7 offspring in drone cells and 6 in worker cells, although numbers are normally 5-6 and 4-5, respectively (Ifantidis, 1984; Martin, 1994, 1995). However, the actual parasitization levels can be lower and are actually difficult to estimate, while the region and the bee tribes observed, and breeding towards tolerance, all influence reproductive performance (De Jong et al., 1984; De Guzman et al., 2007; Rosenkranz et al., 2010).

Fecundity of $V$. destructor is considered to be among the most important fitness parameters that affect the population dynamics and parasitization levels, especially in drone brood. Furthermore, since it is known that $V$. desctructor infest drone cells 5 to 8 times more than the worker cells (Schulz, 1984; Woyke, 1987; Fuchs, 1990; Martin 1995), this attribute prompted a biotechnical control method referred to as the drone brood trapping method, in which mites are first trapped in drone brood and then removed from the hive (Schulz et al., 1983; Rosenkranz \& Engels, 1985).

The scope of this study was to estimate the population levels and fecundity of $V$. destructor in drone broods of bee colonies located in northern Greece, and to address the question of whether reproductive performance has changed towards tolerance compared to previous related studies. Furthermore, the study aimed to re-evaluate under precise conditions whether early entrapment of Varroa mites into the drone brood cell decreases the mite populations of the succeeding generation. Data analysis and interpretation continue, and information is still being collected on the population dynamics and fecundity of $V$. destructor in an attempt to provide some evidence on region-specific host-parasite interactions that may help improve varroatosis management.

\section{Materials and methods}

The study was carried out in the apiary of the Laboratory of Apiculture and Sericulture of Aristotle University of Thessaloniki in Greece during the spring and early summer of 2004.

\section{Honeybee populations}

An established honeybee population of $A$. melifera was used during the experimental trials. These populations had a case record of considerable $V$. destructor infestations. The bee population consisted of 50 honeybee hives located in Eastern Thessaloniki in Northern Greece. The bee colonies were separated by variable distances between them and were located only a few meters above sea level. The hives used in the trials were standard beehives (frame size $366 \times 222 \mathrm{~mm}$ ) each containing 20 honeycombs. Throughout the trials, a distributed sample of 6 beehives was randomly chosen for experimentation. Colonies were fed with sugar dough through the winter season since in several cases honey stores were considered insufficient for survival. No mite-specific control measures or any kind of chemical treatment were performed and over recent years the colonies had been allowed to swarm freely.

\section{Estimation of mite generations}

To estimate the reproductive performance of $V$. destructor (i.e., number of life Varroa offspring per cell) of succeeding mite generations, the drone cells must be unsealed at a precise time point at which progeny are present and can be distinguished from mothers. To do this, a specific procedure was followed. First, a drone comb was placed in each hive for male bee offspring to be deposed in each cell by the queen. Then each day the number of the new sealed drone cells was recorded and marked. This was made possible by the construction of a detailed drone cell map consisting of transparent plastic foil membranes in which each day the new sealed cells were marked with a waterproof colored marker. Based on the drone cell map, the detailed age of each sealed cell could be estimated with accuracy. In addition, since ontogenesis of $V$. destructor coincides with the developmental stages of the bee host $A$. melifera, its distinctly morphological features were also used as a criterion. Therefore, a number of cells were carefully opened and inspected during the period in which host pupae had pink and purple colored eyes and their dorsal shield was yellow (Ifantidis, 1983). After this developmental stage, such observations are no longer useful given that the parent mites and their offspring are no longer distinguishable and counts could be biased (Ifantidis, 1983).

Inspections were carried out over two successive periods in spring and early summer. The first observation period started on April $20^{\text {th }}$ during which the first treatment was carried out while the second started on May $20^{\text {th }}$ during which the second treatment was carried out. Each observation period lasted approximately two weeks, depending upon the drone development. Inspections were carried out of a sample that corresponded to $10-30 \%$ of the sealed drone cells.

\section{Fecundity of $V$. destructor}

The drone combs were successively removed each day from the beehives and transferred to the laboratory for inspection in a stereoscope. The comb was divided into four parts and a representative number of cells was randomly chosen from each quarter and opened. Individuals were carefully pulled out of their cells with forceps. The body of each individual and its evacuated cell were examined using cold light apparatus. The number of the anchored mites on the drone brood, as well as the number of those trapped in the base of the cell and free moving mites, was also recorded.

After estimating the parental mite pressure and the number of mite progenies, each of the drone combs was placed inside a parallelogram shaped cage. The cages consisted of a thin steel mesh $(2 \times 2 \mathrm{~mm})$ that held each of the drone brood. Each of the cages allows access from the drone brood to the mites after breaking the sealed cells when the drone has emerged, but not access to the drone host. Each of the drone brood confined on the mesh tray was placed vertically on a transparent plastic foil which had commercial Vaseline ${ }^{\circledR}$ around the edge to trap the free-moving mites. The mesh trap construction was placed inside environmental chambers at $35-36^{\circ} \mathrm{C}$ and the drone brood was left to breed until the adult emerged. Each day, the plastic foil was inspected for newly trapped mites. Each day, all mite individuals (e.g., adult daughter mites and nymphal stages) were counted and removed. Successive observations were carried out until the end of drone emergence.

In order to count the phoretic mites, the emerged drone adults were placed inside a soap-water solution (5\%) for $24 \mathrm{~h}$ and the mixture was shaken in order to wash all mites. Mites and bees were counted to establish absolute infestation rates (number of mites/number of bees $\times 100$ ).

Finally, for confirmation, all the unsealed drone brood that was used during each of the treatments was further examined in the laboratory to assess the absolute number of cells infested. The total number of infected cells in each of the drone comb was carefully counted. Cell infection was identified according to the presence of characteristic white-colored Varroa excreta.

\section{Statistical analysis}

Data were examined to verify whether they met the assumptions of normality, and all statistical comparisons were made using two-sample t-tests. The hypothesis of $\mathrm{H}_{0}: \mathrm{m}_{1}-\mathrm{m}_{2}=\mathrm{d}_{0}$ versus $\mathrm{H}_{1}: \mathrm{m}_{1}-\mathrm{m}_{2} \neq \mathrm{d}_{0}$, where $\mathrm{m}_{1}$ and $m_{2}$ are the population means and $\mathrm{d}_{0}$ is the hypothesized difference between the two population means, was tested for a $\alpha=0.05$ level of significance. For comparative reasons, a two-sample non-parametric Mann-Whitney rank test was also performed to test the hypothesis of $H_{0}: n_{1}=n_{2}$ versus $H_{1}: n_{1} \neq n_{2}$, where $n$ is the population median. Finally, lin- 
ear regression was performed to detect covariance between drone brood and mite population variables.

\section{Results}

\section{Parental mite load in drone brood}

Figure 1 shows the parasitization levels (\%) in a drone brood of $A$. melifera caused by parental $V$. destructor mites during the two successive treatments. In general, the parasitization level was high in all of the hives examined and during both treatment periods. The number of cells that were occupied by Varroa parental mites before capping, and during the first observation period, was significantly higher than during the second ( $t=4.14518, P=0.0136$, Mann-Whitney: $\mathrm{P}=0.005)$. In particular, during the first treatment period, parasitization ranged from 30-50\% $\left(\mathrm{m}_{1}: 36.084, \mathrm{SE}: 6.476, \mathrm{n}_{1}: 41.6\right)$, while during the second it ranged from 18 to $23 \%\left(\mathrm{~m}_{2}: 7.81, \mathrm{SE}: 2.139, \mathrm{n}_{2}: 11.2\right)$.

\section{Multiple parasitization}

Multiple parasitization caused by $V$. destructor parents per cell of $A$. melifera drone brood is shown in Figure 2. This infection load corresponds to the number of the inspected cells in which more than one parental mite was discovered with respect to the total number of cells inspected (values in brackets). During the first observation period, and in all experimental hives, $10-35 \%$ of the drone cells were infested with

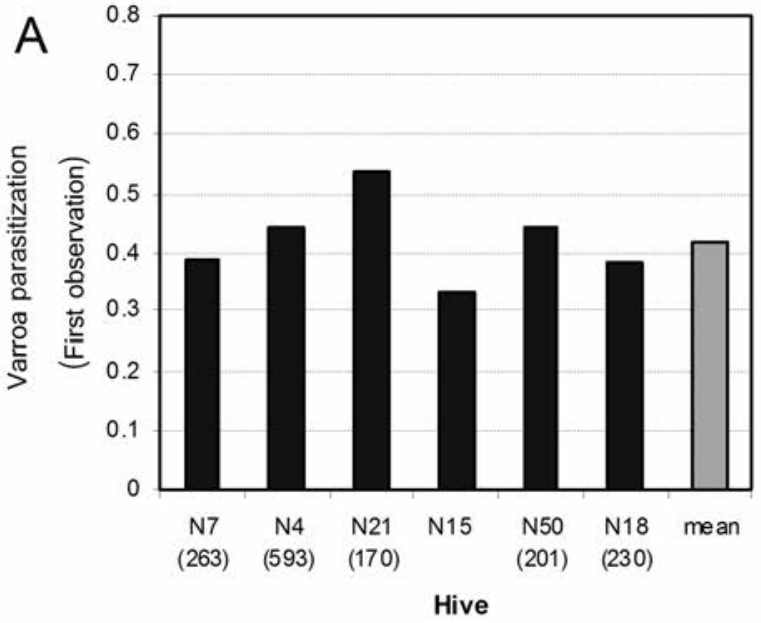

Cells inspected / drone brood

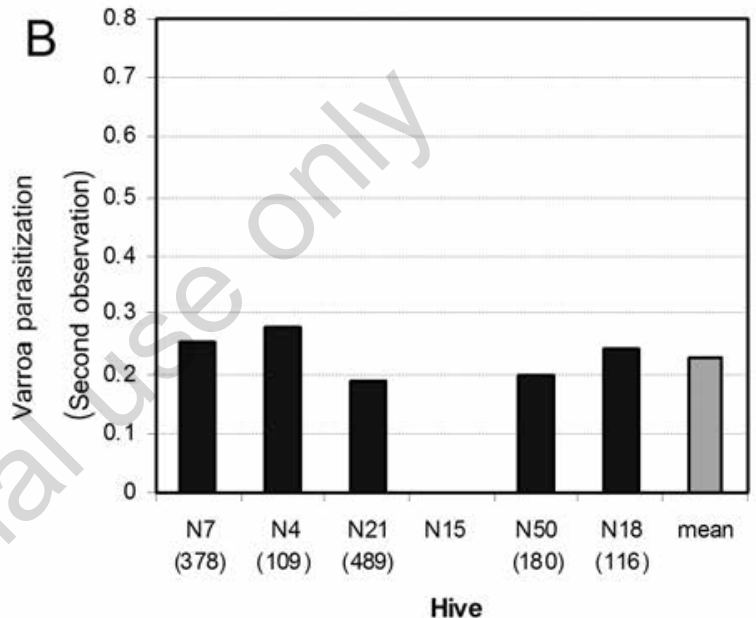

Cells inspected / drone brood

Figure 1. Parasitization levels (\%) in drone brood of $A$. melifera caused by parental $V$. destructor mites during the (A) first and (B) second treatments.

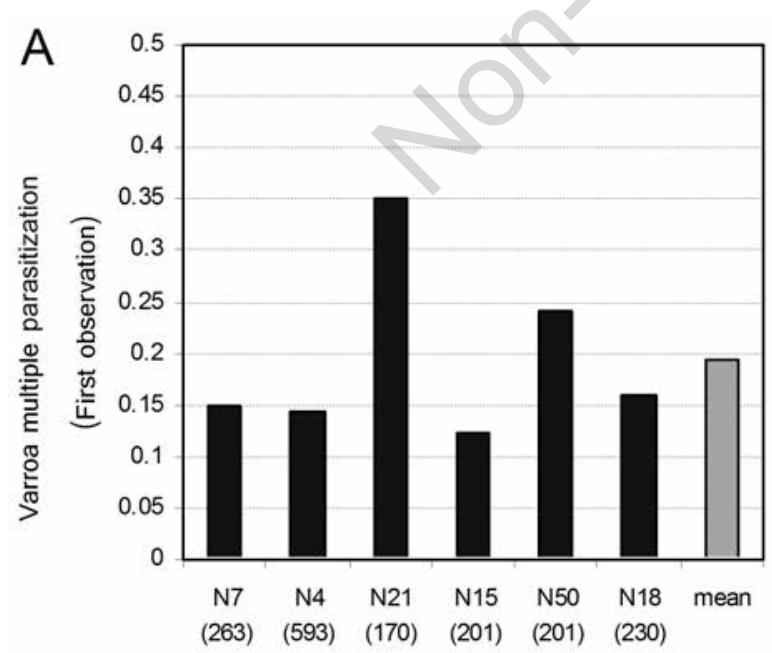

Hive

(cells inspected / drone brood)

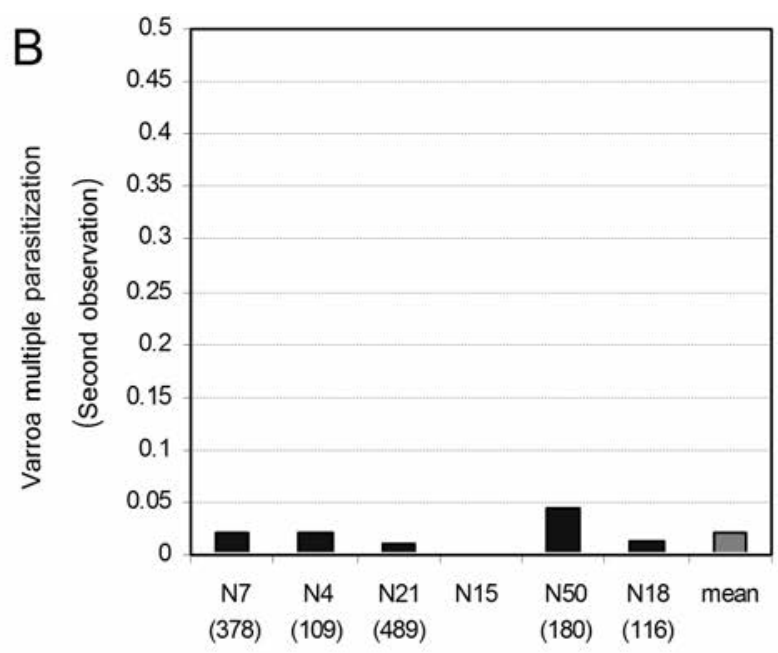

Hive

(cells inspected / drone brood)

Figure 2. Multiple parasitization levels per drone brood cells caused by $V$. destructor mites of $A$. melifera during the (A) first and (B) second treatments. Multiple parasitization corresponds to the percentage of cells infected with more than one parental mite. 
more than one parental mite before capping $\left(\mathrm{m}_{1}: 16.705\right.$, SE:4.075, $\mathrm{n}_{1}=15.5$ ) while during the second observation period the multiple infections corresponded to $0.2-5 \%$ of the total drone cells inspected $\left(\mathrm{m}_{2}: 1.857, \mathrm{SE}: 0.609, \mathrm{n}_{2}=2\right)$ and were, therefore, significantly lower ( $\mathrm{t}=3.325, \mathrm{P}=0.006$, Mann-Whitney: $\mathrm{P}=0.0081$ ).

Figure 3 shows a comparison of the new sealed drone brood infected with one, 2,3 , and more than 3 mites for each time treatment. During the first observation period, over $50 \%$ of the inspected cells were occupied by only one mite, while during the second period the number of inspected cells occupied by only one mite was significantly lower at close to $40 \%$ ( $\mathrm{t}=6.18, \mathrm{P}=0.000$, Mann Whitney: $\mathrm{P}=0.008)$. Furthermore, during the first observation, the number of cells occupied with 2 mites corresponded to $20 \%$ of the total parasitization levels, while during the second observation period, this dropped by $3 \%(\mathrm{t}=4.06, \mathrm{P}=0.010$, Mann Whitney: $\mathrm{P}=0.0081$ ). Finally, a surprisingly higher number of cells infected with more than 3 mites was observed during the second observation time compared to the first $(\mathrm{t}=-3.02, \mathrm{P}=0.029$, Mann Whitney: $\mathrm{P}=0.0137)$.

\section{Reproductive capacity and absolute mite infections}

The reproductive capacity of Varroa mites is shown in Figure 4 corresponding to the number of progeny mites in each cell. There were significant differences in reproduction of $V$. destructor between the two observation time periods $(\mathrm{t}=-3.29, \mathrm{P}=0.009$, Mann-Whitney: $\mathrm{P}=0.025)$

A

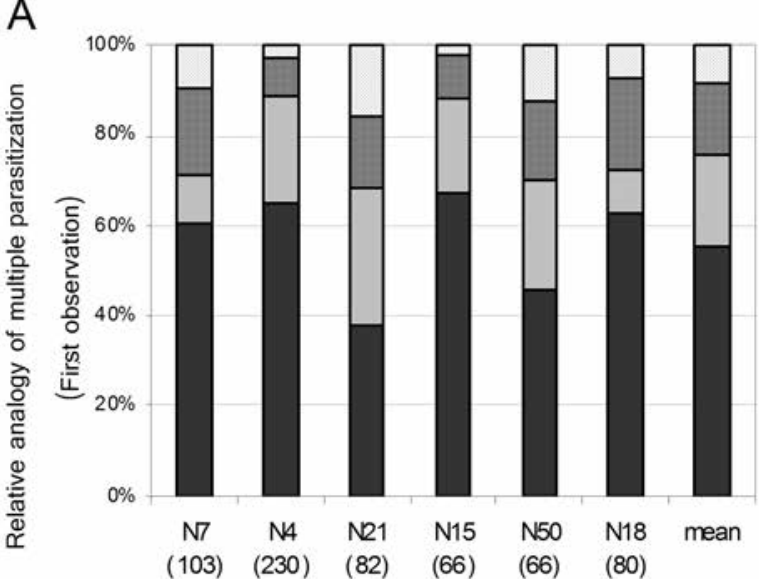

Hive

(number of cells / drone brood)
B

$\square>3$
$\square 3$
$\square 2$
$\square 1$
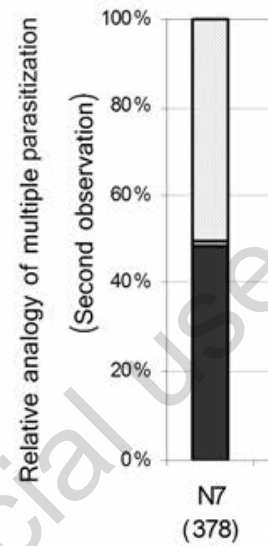

(378)

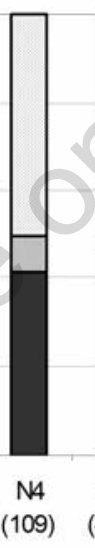

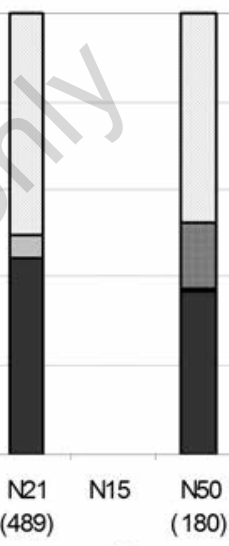
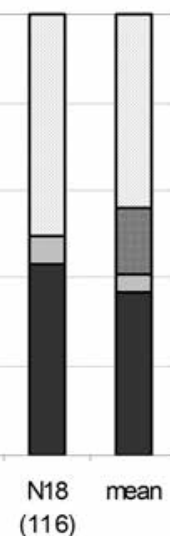

Hive

(number of cells / drone brood)

Figure 3. $V$. destructor multiple parasitization levels in drone brood cells of $A$. melifera and during the (A) and (B) second treatments (i.e., first and second mite generations). Comparison of multiparasitization corresponds to 4 different mite loads $(1,2,3$ and $>3$ mites per inspected cell).

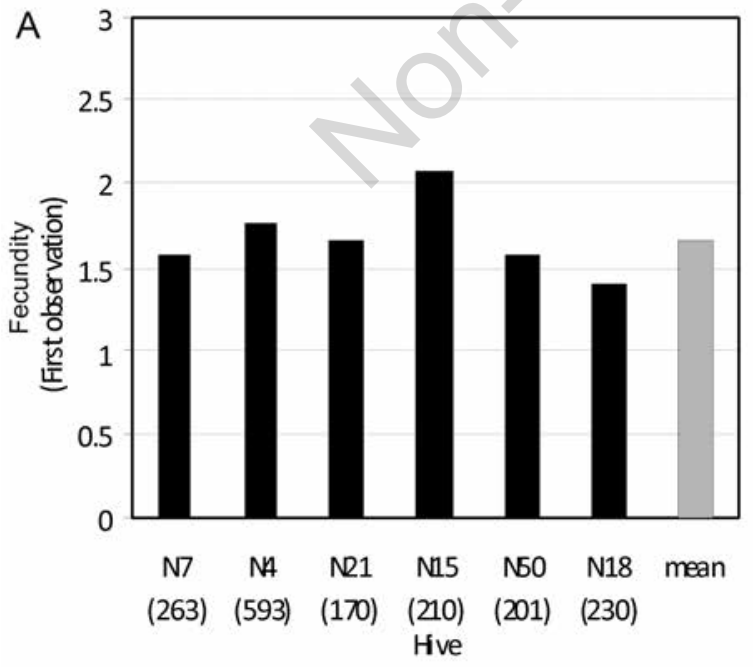

(cells infected/dronebrood)

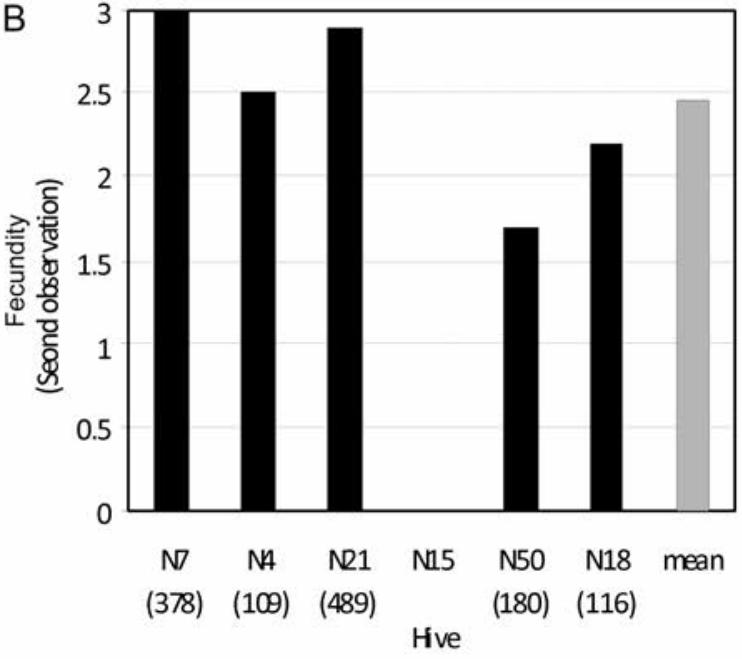

(cells infected/drane brood)

Figure 4. Fecundity of $V$. destructor parasitizing $A$. melifera drone brood during the (A) first and (B) second observation periods (i.e., first and second mite generations). Fecundity corresponds to the actual number of female progeny produced by parental mites that entered the cell before capping and were discovered during inspection. 
and fecundity ranged from 1.5 to 3 progeny per female mite $\left(\mathrm{m}_{1}: 1.620\right.$, $\mathrm{SE}=0.09, \mathrm{n}_{1}=1.62$ and $\mathrm{m}_{2}: 2.02, \mathrm{SE}: 0.24, \mathrm{n}_{2}=2.5$ for the first and second observation periods, respectively).

Figure 5 presents the absolute number of mites (mothers and progeny) and drones for each hive and for the two successive treatments. The total number of mites corresponds to those that were free moving and that anchored on drone adults. The number of drones ranged from 275 (N50) to 1041 (N7) and from 140 (N18) to 1076 (N7) for the first and second observation periods, respectively; no significant differences were found $\left(\mathrm{m}_{1}: 631.0, \mathrm{SE}: 130.6, \mathrm{~m}_{2}: 467.4, \mathrm{SE}: 194, \mathrm{t}=0.74, \mathrm{P}=0.501\right.$, Mann-Whitney: $\mathrm{P}=0.522, \mathrm{n}_{1}: 549, \mathrm{n}_{2}: 220$ ). In contrast, the absolute number of mites during the first period ranged from 244 (N15) to 1343 (N7) and was significantly higher compared to that observed during the sec- ond generation and which ranged from 17 (N18) to 352 (N21), respectively $\left(\mathrm{m}_{1}: 619.4, \mathrm{SE}: 185.8, \mathrm{~m}_{2}: 118.2, \mathrm{SE}: 64, \mathrm{t}=2.86, \mathrm{P}=0.046\right.$, MannWhitney: $\mathrm{P}=0.025, \mathrm{n}_{1}: 435.5, \mathrm{n}_{2}: 40$ ).

Figure 6 shows the linear regressions between absolute number of mites (mothers and progeny) and drone brood adults of each experimental hive, and for the two successive observations that were carried out during the two successive treatments in spring and early summer. In both cases, positive correlations were observed between the numbers of drone brood and Varroa mites. Therefore, the increase in drone density results in a significant increase in the number of mites during the first $\left(\mathrm{y}=0.830+1.153 \mathrm{x}, \mathrm{F}=8.851, \mathrm{P}=0.41, \mathrm{R}^{2}: 0.689\right)$ (Figure 1) and the second $\left(\mathrm{y}=0.319+0.968 \mathrm{x}, \mathrm{F}=45.276, \mathrm{R}^{2}: 0.938, \mathrm{P}=0.07\right)$ (Figure 2) observation.
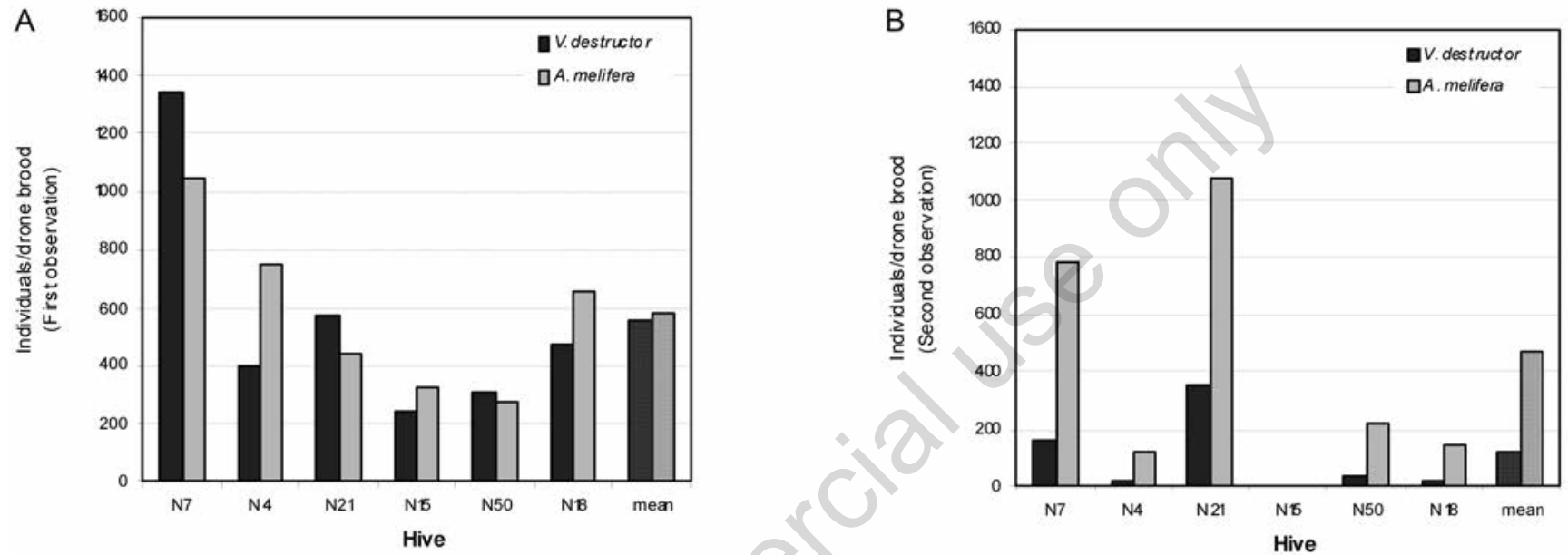

Figure 5. Absolute counts of total parasitic load of $V_{\cdot}$ jacobsoni (mite parents and offspring) and total number of emerged A. melifera brood (adult drones) during the (A) first and (B) second treatments (i.e., first and second mite generations).
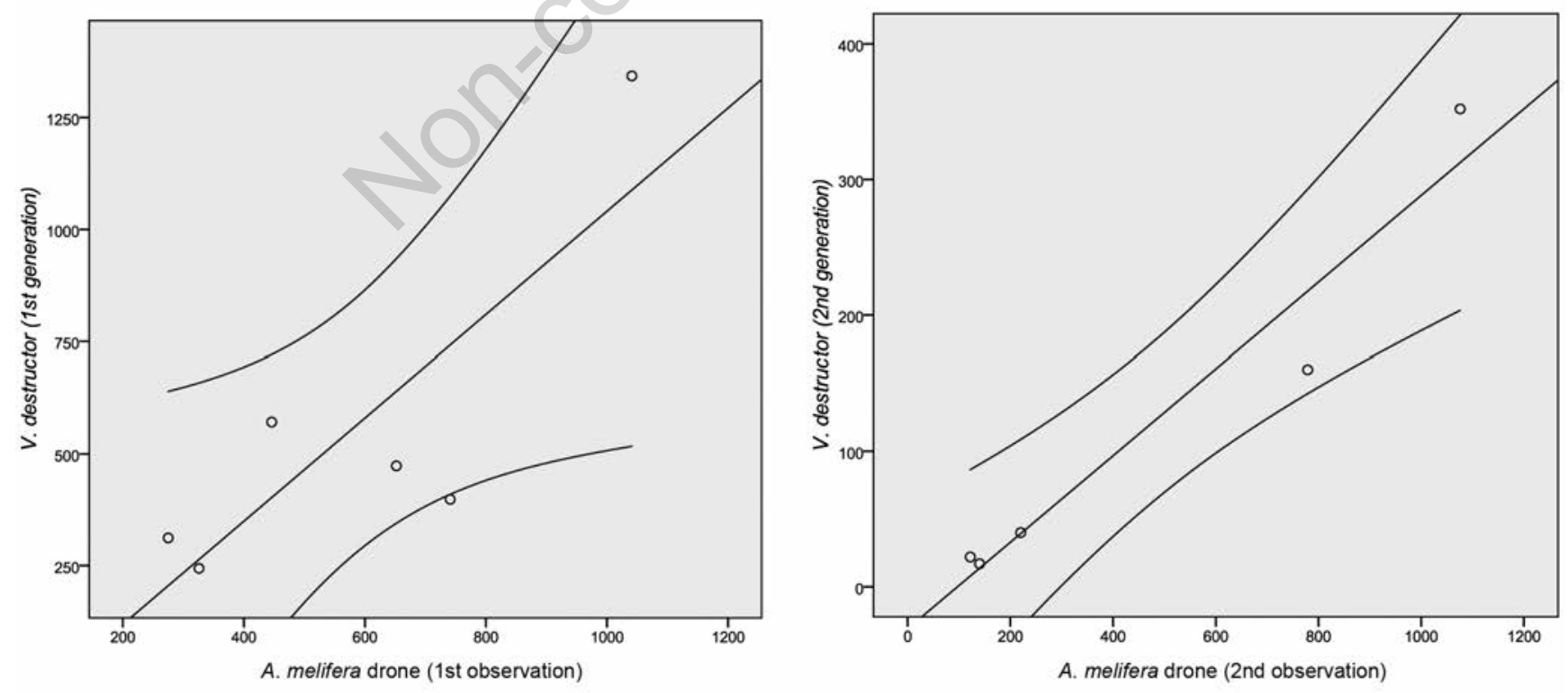

Figure 6. Linear regression between total parasitic load of $V$. destructor (mite parents and offspring) and total number of emerged $A$. melifera brood (adult drones) during (A) the first and (B) second treatments (i.e., first and second mite generations. Regressions for parameter estimates were based on data shown in Figure 5). 


\section{Mite excreta and cell infestation levels in drone brood}

Figure 7 illustrates the total number of cells in each drone comb and the number that was infested by mites as estimated by mite excreta after adult emergence. No significant differences were found in the number of infested and non-infested cells during the first observation period $\left(\mathrm{m}_{1}: 105.2, \mathrm{SE}: 25.0, \mathrm{~m}_{2}: 170.0, \mathrm{SE}: 40.0, \mathrm{t}=-1.38, \mathrm{P}=0.203\right.$, MannWhitney: $\left.\mathrm{P}=0.0656, \mathrm{n}_{1}: 81.0, \mathrm{n}_{2}: 142.5\right)$. In contrast, during the second observation, the number of infested cell was significantly lower than non-infested cells $\left(\mathrm{m}_{1}: 27.6, \mathrm{SE}: 8.1, \mathrm{~m}_{2}: 262.8, \mathrm{SE}: 69.0, \mathrm{t}=-3.39, \mathrm{P}=0.027\right.$, Mann-Whitney: $\mathrm{P}=0.012, \mathrm{n}_{1}: 20, \mathrm{n}_{2}: 340$ ).

Figure 8 shows the percentage of parasitization levels in drone brood cells as estimated by mite counts performed during the first and second observation periods on a representative number of cells, and by cell infections that were estimated by mite excretes present on the total number of unsealed cells observed at the end of each treatment. No significant differences were found in the parasitization levels estimated by representative mite counts performed during the drone breeding period or by observing mite excretes after drone emergence. Parasitization levels were close to $40 \%$ during the first observation period $\left(\mathrm{m}_{1}: 0.402, \mathrm{SE}: 0.029, \mathrm{~m}_{2}: 0.382, \mathrm{SE}: 0.022, \mathrm{t}=1.05\right.$, $\mathrm{P}=0.323$, Mann-Whitney: $\mathrm{P}=0.378, \mathrm{n}_{1}: 0.4160, \mathrm{n}_{2}: 0.3730$ ) and close to $10 \%\left(\mathrm{~m}_{1}: 0.109, \mathrm{SE}: 0.011, \mathrm{~m}_{2}: 0.104, \mathrm{SE}: 0.0073, \mathrm{t}=0.36, \mathrm{P}=0.731\right.$, MannWhitney: $\mathrm{P}=0.834, \mathrm{n}_{1}: 0.112, \mathrm{n}_{2}: 0.112$ ) during the second observation period, regardless of the estimation method used.
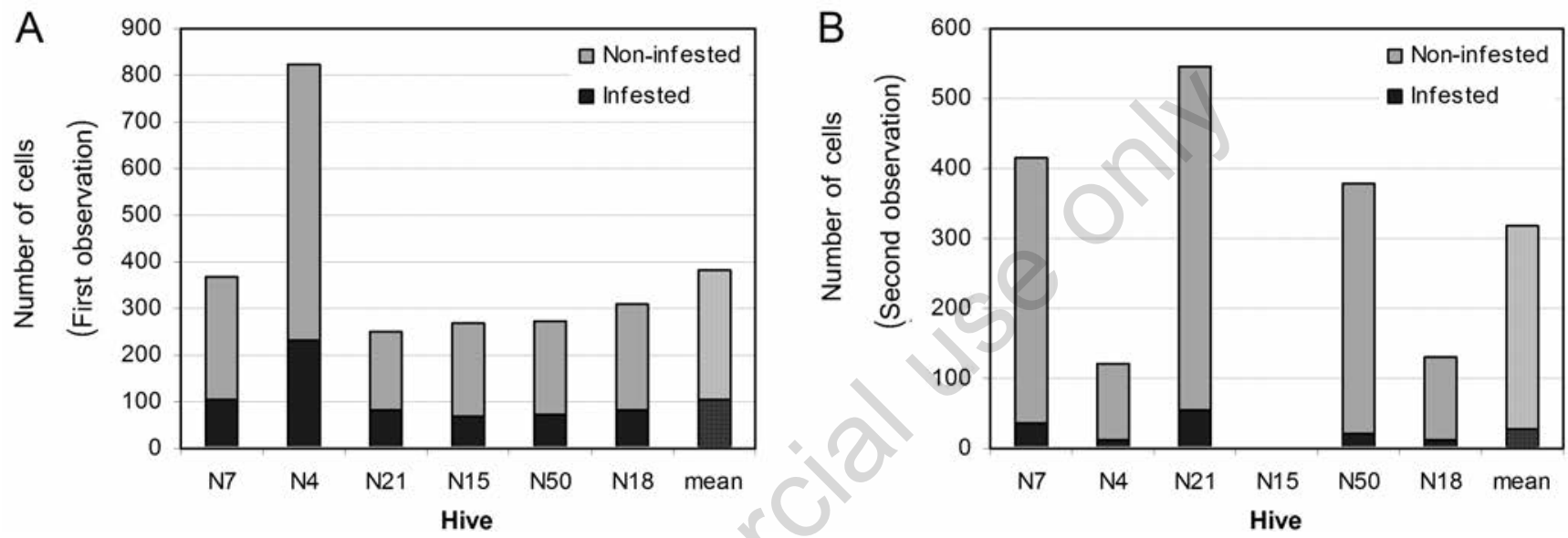

Figure 7. Total number of infested and non-infested $A$. melifera drone brood cells based on $V$. destructor excretes during (A) the first and (B) second treatments (i.e., first and second mite generations).
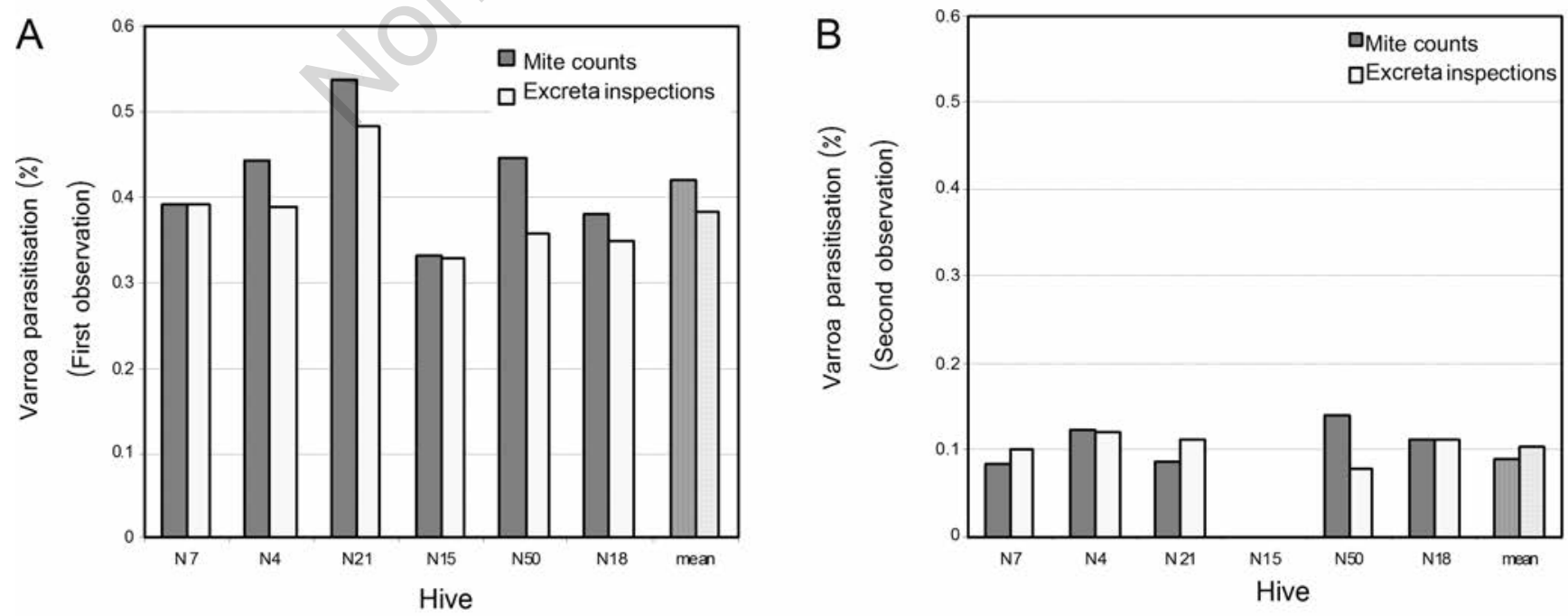

Figure 8. Percentage of infested $A$. melifera drone brood cells by $V$. destructor estimated by mite counts, after drone emergence, and by excreta inspection during (A) the first and (B) second treatments (i.e., first and second mite generations). 


\section{Discussion}

The parasitic species $V$. destructor causes some of the most serious damage to bee colonies worldwide. This study evaluates parasitization levels and reproductive capacity of the drone brood of $A$. melifera in Northern Greece and during two successive observation times. The observation periods were chosen because at these times the mite completes, on average, less than two reproductive cycles (Fries \& Rosankranz, 1996).

Results show that the parasitization level in the drone brood was extremely high during the first observation periods (close to 40\%) although this was significantly lower during the second observation period (dropping to close to 20\%). The fact that the inspected drone brood of the first treatment was finally removed and replaced with a new one was probably the reason why there were significantly lower mite population levels detected during the second treatment since the initial parasitization level of the hives was removed. These results agree with those from similar studies conducted in other regions (Engels et al., 1984; Maul et al., 1988; Rosenkranz \& Renz, 2003; Calderone, 2005) and show the usefulness of the trapping comb method which, along with other measures, could be used in Greece as a potential biotechnical approach to remove mites from beehives and decrease the initial parasitic load.

The multiple parasitization per drone brood cells of $V$. destructor was lower compared to cell infections caused by single mites, especially during the first observation period. Therefore, during the first generation, more than the half the inspected cells were occupied with only one mite while during the second period the number of inspected cells occupied with only one mite was lower. In contrast, a surprisingly higher percentage of multiparasitization (e.g., >3 mites/cell) was observed during the second observation period. This could be related to the higher fecundity rates that were registered during the second generation, as well as to the lower number of drone brood cells that were available for occupation. As a result, multiple parasitization was extremely high during that period.

Although it is generally difficult to evaluate the observed multiple parasitization levels, in a behavioral context it is known that the Varroa mites must invade brood cells as quickly as possible because they cannot reproduce on adult bees (Boot et al., 1994). To the best of our knowledge, there is no evidence to suggest that there is a preferential mite invasion into unoccupied cells and the observed invasions of more than one mite into brood cells could be related to the distance between the mite present on the bee and the brood cells. In addition, the total parasitic load of the colonies, including also the parasitized worker brood, could exert some influence on the observed multiple parasitization levels.

Nevertheless, although it is difficult to interpret the observed differences in triple infections between first and second observations, some studies relate cell infections to bee behavior, the total number of mites, as well as to the number of cells available for invasion. According to Boot et al. (1994), the mites invade the cells when a bee is present just in front of the cell opening and this procedure is quite fast (few minutes). Therefore, differences in observed multiple invasions could be due to the ratio of the mites on bees and the available cells to be occupied as quickly as possible. Furthermore, since infested cells seem to be just as attractive to mites as non-infested cells (Fuchs, 1985), the distance between mite and cell may be the key factor affecting the number of cells occupied by more than one mite, while the temporary immobilization of female Varroa mites at the bottom of the open brood cells (Ifantidis, 1988) permits additional mites to enter without directly interfering with the mite inhabitants already present.

Concerning the actual reproduction rate of $V$. destructor, this is generally difficult to be measured since it depends, among others, on mite fertility and not only fecundity (Rosenkranz et al., 2010). Therefore, in the current study, we address the challenge of measuring observed fecundity that corresponds to the number of viable adult offspring per mother mite. More precisely, it was found that number of viable offspring in drone broods was close to 1.7 during the first observation period and close to 2 during the second. The results of $V$. destructor obtained in this study are within reasonable limits of the different values reported by earlier studies (Schultz, 1984; Büchler, 1994; Ifantidis, 1990; Martin, 1994; Donze \& Guerin, 1994; Martin, 1995). In worker cells, for instance, the actual mean number of mature daughters per parental mite is recorded to be 1.3 (Schultz, 1984), 1.4 (Büchler, 1994), 1.45 (Martin, 1994), or even 0.86 , which is much lower (Ifantidis, 1990).

On the other hand, although in the drone brood all offspring theoretically have the same possibility of developing fully, because the period of sealed brood is longer than in worker cells (approx. 14 days), the reproductive rate differs among drone and worker brood (Dade, 1977; Boot et al., 1992; Donze \& Guerin, 1994; Martin 1995). According to Martin (1995), it reaches 4 individuals, while this number drops to 1.7 (Ifantidis, 1984) or 2.2 (Martin 1995) when the mean number of viable female offspring per mother mite is taken into account (Ifantidis, 1990).

Therefore, although it is known that mite populations vary according to bee genotype, mite genotype, geographical location, and climatic conditions, the levels of drone brood parasitization in the current study are slightly lower than the levels reported from other countries (Rosenkranz, 1999; De Guzman et al., 2007; De Jong et al., 1984; Calderon \& Venn, 2008). However, it is quite difficult to judge whether the low mite reproduction observed in the current study is the result of bee colony tolerance towards infestation or whether other factors play a role. It is known, for instance, that selective breeding of $A$. melifera colonies is not only correlated with the amount of brood and related honey yields, but also to the colony performance towards parasites (Spivak \& Gilliam, 1993; Spivak, 1996; Rosenkranz, 1999; Lodesani et al., 2002; Rosenkranz et al., 2010). Since in the current work there is no available information concerning the total number of the worker brood, the actual strength of the colonies towards mite parasitization and the observed lower fecundity levels could also be related to other factors.

However, these results suggest a high correlation between the drone brood and mite populations, and the lower reproductive capacity recorded could also be due to a lower colony population strength. It is thought that mites have a higher probability of causing infection if more brood cells are available for invasion, and this affects the populations (Boot $e t$ al., 1993, 1994; Martin \& Kepm, 1997). In addition, mites seem to spend longer periods in a phoretic phase when brood is scarce (Calis et al., 1990; Lodesani et al., 2002).

In addition, there were no significant differences in the parasitization level as estimated by absolute measures and by examining the mite excreta; this method can also be used to calculate initial parasistization levels.

Furthermore, mite population in the experimental colonies decreased through the study to significant levels after drone brood removal. Considering that the invasion potential of Varroa mites into drone brood cell is significantly higher than in worker cells (Fuchs, 1990) current results performed in Greek drone broods are in agreement with prior findings (Schulz et al., 1983; Crane, 1984; Rosenkranz \& Engels, 1985; Boecking \& Drescher, 1992; Boot et al., 1994) and support the view that drone brood trapping in early spring can be used as a biotechnical method to mitigate Varroa infection levels in bee colonies.

\section{Conclusions}

Although Varoatosis has been considered to be among the most serious problems in beekeeping for the last 30 years, research is still ongoing to provide a rational means to find a solution (Conte \& Gregorc, 2009; Le Conte et al., 2010; Carreck et al., 2010). The results obtained in the current study, in general, agree with related studies that were 
conducted in other regions (Maul et al., 1988; Bailey \& Ball, 1991; Rosenkranz \& Renz, 2003; Calderone, 2005; Fakhimzadeh, 2001; Lodesani, 2004; Delaplane et al., 2005). Slight differences compared to other studies (Rosenkranz, 1999; De Guzman et al., 2007; De Jong et al., 1984; Calderon \& Venn, 2008) could be explained by the tolerance of different honeybee colonies towards infestation in different geographical regions, and other factors could also play a role.

Given our results, it is feasible that the reproductive potential and the Varroa infection levels are still quite high and remain an important beekeeping issue. Therefore, improvement and development of suitable new diagnostic tools to recognize infestation levels are essential to estimate region specific epidiological aspects of Varroa. Furthermore, the development and optimization of safe and effective rational management options, including the mite trapping technique, may improve beekeeping practices towards integrated management of Varroa. In conclusion, since mite reproduction is an essential specific regional characteristic, increasing our knowledge of the reproductive performance of $V$. destructor in bee colonies of Northern Greece may provide the basis for the development of new control methods. In spite of this, more work should also be carried out to better understand Varroa pathogenesis in relation to host and other factors in order to maintain low parasitization levels.

\section{References}

ANDERSON D.L., TRUEMAN W.H., 2000 - Varroa jacobsoni (Acari: Varroidae) is More than one Species. Exp. Appl. Acarol. 24: 165189.

BAILEY L., BALL B.V., 1991. - Honey Bee Pathology. Academic, London.

BOECKING 0., DRESCHER W., 1992 - The removal response of Apis melifera L. colonies to brood in wax and plastic cells after artificial and natural infestation with Varroa jacobsoni Oud. and to freezekilled brood. Exp. Appl. Acarol. 16: 321-329.

B00T W.J., CALIS J.N.M, BEETSMA J., 1992 - Differential periods of Varroa mite invasion into worker and drone cells of honey bees. Exp. Appl. Acarol. 16: 295-301.

BO0T W.J., CALIS J.N.M., BEETSMA J., 1993 - Invasion of Varroa jacobsoni in to honey bee brood cells: a matter of chance or choice? J. Apic. Res. 32: 167-174.

BO0T W.J., BEETSMA J., CALIS J.N.M., 1994 - Behaviour of Varroa mites ivading honey bee brood cells. Exp. Appl. Acarol. 18: 371-379.

BÜCHLER R., 1994 - Varroa tolerance in honey bees - occurrence, characters and breeding. - Bee World 49: 6-18.

CALDERONE N.W., 2005 - Evaluation of drone brood removal for management of Varroa destructor (Acari: Varroidae) in colonies of Apis melifera (Hymenoptera:Apidae) in the northeastern United States. J. Econ. Entomol. 98: 645-650.

CALDERON A.R., VEEN J.W., 2008 - Varroa destructor (Mesostigmata: Varroidae) in Costa Rica: population dynamics and its influence on the colony condition of Africanized honey bees (Hymenoptera: Apidae). Int. J. Trop. Biol. 56: 1741-1747.

CALIS J.N.M., B00T W.J., BEETSMA J., 1990 - Transfer from cell to cell. How long do Varroa mites stay on adult bees. In: RITTER W., (ed.). Proceedings from the International Symposium on Recent Research of Bee Pathology, 5-7 September1990, Gent Belgium. Janssen Pharmaceutica, Beerse, Belgium: 45-46.

CARRECK N.L, BALL B.V., MARTIN S.J., 2010 - Honey bee colony collapse and changes in viral prevalenceassociated with Varroa destructor. J. Apic. Res. 49: 93-94.

CONTE Y., GRGORC A., 2009 - Bee mortality and bee surveillance in Europe, EFSA-Report. Available from: http://www.efsa.europa.eu

CRANE E., 1978 - The Varroa mite. Bee World 59: 164.
CRANE E., 1984 - Living with Varroa in Japan. Bee World 65: 149.

COLIN M.E., FERNÁNDEZ G.P., BEN HAMIDA B., 1997 - Varroosis. In: Colin M.E., Ball B.V., Kilani M., (eds.). Bee disease diagnosis (Options Méditerranéennes: Série B. Etudes et Recherches; n. 25). CIHEAM-IAMZ, Zaragoza: 121-142.

DADE H.A., 1977 - Anatomy and dissection of the honeybee. - IBRA, London, UK.

DE GUZMAN L., RINDERER T., FRAKE A., 2007 - Growth of Varroa destructor populations in Russian Honey bee (Hymenoptera: Apidae) colonies. Ann. Entomol. Soc. Am. 100: 187-195.

DE JONG D., GONCALVES L., MORSE R., 1984 - Dependence of climate of the virulence of Varroa jacobsoni. Bee World 65: 117-121.

DELAPLANE K., BERRY J., SKINNER J., PARKMAN J., HOOD W., 2005 Integrated pest management against Varroa destructor reduces colony mite levels and delays treatment threshold. J. Apic. Res. 44: 157-162.

DONZE G., GUERIN P.M., 1994 - Behavioral attributes and parental care of Varroa mites parasitizing honeybee brood. - Behav. Ecol. Sociobiol. 34: 305-319.

EVANS G.0., 1992. - Principles of acarology. CAB International, Wallingford.

ENGELS W., ROSENKRANZ P., HERTL F., STAEMMLER G., 1984 - Effect of drone brood removal on Varroa infested honey bee colonies. Apidologie 15: 246-248.

FAKHIMZADEH K., 2001. Effectiveness of confectioner sugar dusting to knock down Varroa destructor from, adult honey bees in laboratory trials. Apidologie 32: 139-148.

FRIES I., CAMAZINE S., SNEYD J., 1994 - Population dynamics of Varroa jacobsoni - A model and a review. Bee World 75: 5-28.

FRIES I., A., ROSENKRANZ P., 2006 - Survival of mite infested (Varroa destructor) honey bee (Apis melifera) colonies in a Nordic climate. Apidologie 37: 564-570.

FRIES I., ROSENKRANZ P., 1996. - Number of reproductive cycles of Varroa jacobsoni in honey-bee (Apis melifera) colonies. - Exp. Appl. Acarol. 20: 103-112.

FUCHS S., 1985 - Fuchs S. Untersuchungen zur quanitativen Abschätzung des Befalls von Bienenvölkern mit Varroa jacobsoni Oudemans und zur Verteilung des Parasiten im Bienenvolk. Apidologie 16: 343-368.

FUCHS S., 1990 - Drone brood cell preference of Varroa jacobsoni Oud. in colonies of Apis melifera carnica. Apidologie 21: 193-199.

LE CONTE Y., ELLIS M., RITTER W., 2010 - Varroa mites and honey bee health: can Varroa explain part of the colony losses? Apidologie 41: $1-11$.

LODESANI M., CRAILSKEIM K., MORITZ R.F.A., 2002 - Effect of some character on the population growth of mite Varroa jacobsoni in Apis melifera $\mathrm{L}$ colonies and results of a b-directional selection. J. Appl. Entomol. 126: 130-137.

LODESANI M., 2004 - Control strategies against Varroa mites. Parassitologia 46: 277-279.

MARTIN S.J., 1994 - Ontogenesis of the mite Varroa jacobsoni Oud. in worker brood of the honeybee Apis melifera L. under natural conditions. Exp. Appl. Acarol. 18: 86-100.

MARTIN S.J., 1995 - Ontogenesis of the mite Varroa jacobsoni Oud. in drone brood of the honeybee Apis melifera L. under natural conditions. Exp. Appl. Acarol. 19: 199-210.

MARTIN S.J, KEPM D., 1997 - Average number of reproductive cycles performed by Varroa jacobsoni in honey bee (Apis melifera) colonies. - J. Apic. Res. 36: 113-123.

MAUL V., KLEPSCH A., ASSMANNWERTHMULLER U., 1988 - The trapping comb techniqueas part of bee management under strong infestation by Varroa jacobsoni Oud. Apidologie 19: 139-154.

OUDEMANS A. C., 1904 - On a new genus and species of parasitic acari. Notes Leyden Museum., Leyden: 216-222. 
SPIVAK M., GILLIAM M., 1993 - Facultative expression of hygienic behaviour of honey bees in relation to disease resistance. J. Apic. Res. 32: 147-157. brood infested with Varroa jacobsoni Oud and infestation rate of colonies in Thailand. Apidologie 21:311-321.

RATH W., 1999 - Co-adaptation of Apis cerana Fabr. and Varroa jacobsoni Oud. Apidologie 30: 97-110.

ROSENKRANZ P., W. ENGELS, 1985 - Konsequente Drohnenbrutentnahme, eine wirksame biotechnische Massnahme zur Minderung von Varroatose-Schaeden an Bienenvoelkern. Allg. Dtsch. Lmkerztg. 19:265-271.

ROSENKRANZ P., 1999 - Honey bee (Apis melifera L.) tolerance to Varroa jacobsoni Oud. in South America. Apidologie 30: 159-172.

ROSENKRANZ P., RENZ M., 2003 - Varroa destructor infestation of adult bees, workerbrood and drone brood during the season and consequences for treatmentconcepts. Apidologie 34: 509-510.

ROSENKRANZ P., AUMEIER P., ZIEGELMAN B., 2010 - Biology and control of Varroa destructor. J. Invert. Pathol. 103: 96-119.

SCHULZ A., KOENIGER N., RUTTNER F., 1983 - Drohnenbrut als Varroafalle. Allg. Dtsch. Imkerztg 17: 52-54.

SCHULZ A.E., 1984 - Reproduction and population dynamics of the parasitic mite Varroa jacobsoni Oud. and its dependence on the brood cycle of its host Apis melifera L. Apidologie 15: 401-420.

SPIVAK M., 1996 - Honey bee hygienic behaviour and defence against Varroa jacobsoni. Apidologie 27: 245-260.

IFANTIDIS M.D., 1983 - Ontogenesis of the mite Varroa jacobsoni Oud. in worker and drone honeybee brood cells. J. Apic. Res. 22: 200-206.

IFANTIDIS M.D., 1984 - Parameters of the population dynamic of the Varroa mite onhoneybees. J. Apic. Res. 23: 227-233.

IFANTIDIS M.D., 1988 - Some aspects of the process of Varroa jacobsoni mite entrance into honeybee (Apis meUifera) brood cells. Apidologie 19: 387-396.

IFANTIDIS M.D., 1990 - Re-examination of some parameters concerning reproduction of the mite Varroa jacobsoni Oud. In: Proceedings of the International Symposium on Resent Research on Bee Pathology, Gent: 20-26.

WOYKE J., 1987 - Comparative population dynamics of Tropilaelops clareae and Varroa jacobsoni mites on honeybees. J. Apic. Res. 26: 196-202. 